\title{
UTILIZATION OF WHEY FOR THE PREPARATION OF CHOCOLATE MILKSHAKES WITH CHIA (Salvia hispanica L.) ${ }^{1}$
}

\author{
Julimeri Câmara Costa \\ Emanuel Neto Alves de Oliveira \\ Kaísa Mikelly Pereira Oliveira \\ Rerisson do Nascimento Alves \\ Bruno Fonsêca Feitosa ${ }^{2}$ \\ Rosane Liege Alves de Souza
}

\begin{abstract}
Utilization of whey for the preparation of new food products may be an alternative to minimize environmental problems and reduce the disposal of high nutritional value byproducts. This study aimed to prepare chocolate milkshakes with chia by partially replacing milk with whey. Three milkshake formulations were developed: a control formulation (without whey), a formulation containing $36 \%$ milk and $24 \%$ whey, and a formulation containing $24 \%$ milk and $36 \%$ whey. Microbiological parameters, proximate composition, energy value, total solids, titratable acidity, $\mathrm{pH}$, and water activity were evaluated after preparation. The data were subjected to Analysis of Variance in a Completely Randomized Design, and means were compared by Tukey's test at the 5\% significance level. Milkshakes were found to have good microbiological quality, with low counts of thermotolerant coliforms (determined at $\left.45^{\circ} \mathrm{C}\right)(<3 \mathrm{MNP} / \mathrm{g})$ and yeasts and filamentous fungi $(<10 \mathrm{CFU} / \mathrm{g})$. That replacement of milk by whey resulted in a reduction in ash, lipid and energy values and an increase in carbohydrate values. One portion of the developed milkshakes was estimated to provide between 72.12 and 84.52 Kcal. There were no significant differences in titratable acidity, total solids, or water activity between formulations. It is inferred that chocolate milkshakes with chia prepared with partial replacement of milk by whey are a feasible and innovative alternative to minimize environmental impacts. Complementary studies are recommended on storage stability and sensory quality.
\end{abstract}

Keywords: Functional foods. Ice-cold foods. Agro-industrial wastes.

\section{APROVEITAMENTO DO SORO DE LEITE NA ELABORAÇÃO DE MILKSHAKES DE CHOCOLATE COM CHIA (SALVIA HISPANICA L.)}

\section{RESUMO}

O aproveitamento do soro de leite na elaboração de novos produtos pode ser uma alternativa para minimizar problemas ambientais e o desperdício de subprodutos de alto valor nutricional. Assim, objetivou-se elaborar milkshakes de chocolate com chia, substituindo parcialmente o leite por soro de leite. Foram elaboradas três formulações de milkshakes: sem adição de soro controle, com $36 \%$ de leite $/ 24 \%$ de soro e $24 \%$ de leite $/ 36 \%$ de soro. A qualidade

\footnotetext{
${ }^{1}$ How to cite this paper: COSTA, J. C. et al. Utilization of whey for the preparation of chocolate milkshakes with chia (Salvia hispanica L.). ForScience, Formiga, v. 9, n. 1, e00887, jan./jun. 2021. DOI: 10.29069/forscience.2021v9n1.e887.

2 Corresponding author: Bruno Fonsêca Feitosa; E-mail: brunofonsecafeitosa@live.com
} 
microbiológica, composição proximal e análises físico-químicas quanto aos parâmetros valor calórico, extrato seco, acidez total, $\mathrm{pH}$ e atividade de água foram avaliados, após o processamento. Os dados obtidos foram analisados através de Análise de Variância, em Delineamento Inteiramente Casualizado, comparando-se as médias pelo teste de Tukey a nível de 5\% de significância. Verificou-se boa qualidade microbiológica, com baixas contagens para coliformes a $45^{\circ} \mathrm{C}(<3 \mathrm{NMP} / \mathrm{g})$ e fungos filamentosos e leveduriformes $(<10 \mathrm{UFC} / \mathrm{g})$. A inclusão de soro de leite provocou redução nos teores de cinzas, lipídeos e valores calóricos, bem como aumento nos teores de carboidratos. O consumo dos milkshakes indicou que as porções fornecem de 72,12 a 84,52 Kcal. Não houveram diferenças significativas entre os milkshakes para os parâmetros acidez total, extrato seco e atividade de água. Infere-se que a elaboração de milkshakes de chocolate com chia, substituindo parcialmente o leite por soro de leite, pode ser viável e uma alternativa inovadora para minimizar impactos ambientais, sendo recomendadas análises complementares sobre a estabilidade de armazenamento e a qualidade sensorial.

Palavras-chave: Alimentos funcionais. Gelados comestíveis. Resíduos agroindustriais.

\section{INTRODUCTION}

Whey, a by-product of the dairy industry, accounts for 80 to $90 \%$ of the total volume of milk used in cheese production. Whey is rich in organic compounds and retains about 55\% of the nutrients present in milk, needing adequate treatment before disposal to minimize environmental impacts (ALVES et al., 2014; VILELA et al., 2020). Aiming to prevent the waste of this high nutritional value by-product, food industries and researchers have investigated sustainable alternatives for whey utilization. A major application is in the development of novel food products (ALVES et al., 2014).

In recent years, whey has been extensively used in the production of cheese bread (TESSER et al., 2010), sliced bread (OLIVEIRA et al., 2011), whey powder (PERRONE et $a l ., 2014)$, dulce de leche (LIMA; ROCHA, 2016), ice creams (VETTORELLO et al., 2017),

milk spreads (MENESES et al., 2019), and drink mixes (HOLANDA et al., 2020). However, there are no reports in the literature on the use of whey for the preparation of milkshakes.

Brazilian legislation (RDC No. 266/2005) defines ice-cold foods as frozen food products obtained from an emulsion of fats and proteins or from a mixture of water and sugar (BRAZIL, 2005a). The development of new ice-cold food products (such as popsicles, ice creams, and milkshakes) containing whey represents an innovative strategy (VETTORELLO et al., 2017).

There is an increasing demand for food products containing functional ingredients. According to Silva et al. (2014), functional foods provide benefits that go beyond the role of nutrition. Fortified, enriched, and enhanced foods have beneficial health effects when consumed as part of a varied diet (SOUZA et al., 2013). 
Chia (Salvia hispanica L.) seeds are widely known for their functional properties and high contents of polyunsaturated fats, essential amino acids, fibers and antioxidants (CAPITTANI et al., 2012; COELHO; SALAS-MELLADO, 2014). Chia consumption promotes satiety, improves intestinal motility, and reduces the risk of diabetes (MADRUGA; ROCHA; FERNANDES, 2020).

Given the need to find novel applications for whey and vehicles for functional ingredients, this study aimed to develop chocolate chia milkshakes by partially replacing milk with whey and determine the effects of milk replacement on microbiological and physicochemical parameters.

\section{MATERIAL AND METHODS}

This study was conducted at the Federal Institute of Education, Science and Technology of Rio Grande do Norte, Pau dos Ferros-RN campus, Rio Grande do Norte State, Brazil. Ultrahigh temperature (UHT)-treated milk, powdered milk, light cream, 100\% cocoa powder, emulsifier $\left(\right.$ Emustab $\left.^{\circledR}\right)$, table sugar, and chia flour were purchased from a local market. The whey resulting from the manufacture of Coalho cheese was purchased from a cheese factory in Pau dos Ferros-RN. After collection, whey samples were transported to the laboratory in a cool box with ice and then treated at $85{ }^{\circ} \mathrm{C}$ for 15 min to promote enzyme inactivation and fat separation.

Three chocolate milkshake with chia formulations were developed on the basis of preliminary tests: $\mathrm{M}_{1}$, a control formulation (without whey); $\mathrm{M}_{2}$, milkshake containing $36 \%$ milk and 24\% whey; and $\mathrm{M}_{3}$, milkshake containing $24 \%$ milk and $36 \%$ whey. Ingredient proportions are presented in Table 1.

Table 1 - Ingredient composition of chocolate chia milkshake formulations

\begin{tabular}{cccc}
\hline Ingredient (\%) & \multicolumn{3}{c}{ Formulation } \\
\cline { 2 - 4 } & $\mathrm{M}_{1}$ & $\mathrm{M}_{2}$ & $\mathrm{M}_{3}$ \\
\hline UHT milk & 60 & 36 & 24 \\
Whey & 0 & 24 & 36 \\
Powderedmilk & 10 & 10 & 10 \\
Light cream & 10 & 10 & 10 \\
Cocoapowder & 8 & 8 & 8 \\
Emulsifyingagent & 5 & 5 & 5 \\
Table sugar & 5 & 5 & 5 \\
Chia flour & 2 & 2 & 2 \\
\hline
\end{tabular}

Source: Authors (2020).

The first step in the preparation of milkshakes was to mix the liquid ingredients (UHT milk, whey, and light cream). Then, the solid ingredients (milk powder, cocoa powder, table 
sugar, and chia flour) were incorporated using an industrial blender. The resulting mixtures were stored at $-18{ }^{\circ} \mathrm{C}$ for $3 \mathrm{~h}$, until the outer surface began to freeze. Homogenization and gradual addition of emulsifier were performed for $15 \mathrm{~min}$ in an industrial mixer. Milkshakes were stored in polyethylene containers $(200 \mathrm{~mL})$ at $-18^{\circ} \mathrm{C}$ until analysis.

Microbiological quality was assessed after processing by determination of total coliforms (at $35{ }^{\circ} \mathrm{C}$ ), thermotolerant coliforms (at $45{ }^{\circ} \mathrm{C}$ ), and yeasts and filamentous fungi, according to the methods described by Silva et al. (2017).

Physicochemical analysis were performed after processing in triplicate. Water content and total solids were determined by oven-drying samples at $105^{\circ} \mathrm{C}$ for $24 \mathrm{~h}$, ash contents by heating in a muffle furnace at $550{ }^{\circ} \mathrm{C}$ for $6 \mathrm{~h}$, titratable acidity (expressed as lactic acid) by titration with a standard solution of $0.1 \mathrm{~N} \mathrm{NaOH}$, and $\mathrm{pH}$ by using a portable $\mathrm{pH}$ meter calibrated with $\mathrm{pH} 4.0$ and 7.0 buffer solutions, according to Adolfo Lutz Institute methods (ALI, 2008). Lipids (FOLCH; LESS; STANLEY, 1957) and proteins (AOAC, 2016) were also quantified. Carbohydrate contents were then calculated by subtracting the sum of moisture, ash, lipid, and protein contents from 100. Energy values were estimated in accordance with national legislation (BRAZIL, 2005b). Water activity was measured at $25{ }^{\circ} \mathrm{C}$ using a water activity meter (LabStart ${ }^{\circledR}$, Novasina).

Physicochemical data were subjected to analysis of variance in a Completely Randomized Design, followed by Tukey's test at $p<0.05$ for comparison of means. Statistical analysis were performed using Assistat software version 7.7 beta (SILVA; AZEVEDO, 2016).

\section{RESULTS AND DISCUSSION}

Table 2 shows the microbiological properties of chocolate milkshakes with chia.

Table 2 - Microbiological quality of chocolate milkshakes with chia formulated with different concentrations of whey

\begin{tabular}{cccc}
\hline \multirow{2}{*}{ Parameter } & \multicolumn{3}{c}{ Formulation } \\
\cline { 2 - 4 } & $\mathrm{M}_{1}$ & $\mathrm{M}_{2}$ & $\mathrm{M}_{3}$ \\
\hline Total coliforms (MPN/g) & $1.10 \times 10^{3}$ & $1.10 \times 10^{3}$ & $1.10 \times 10^{3}$ \\
Thermotolerant coliforms (MPN/g) & $<3$ & $<3$ & $<3$ \\
Yeasts and filamentous fungi (CFU/g) & $<10$ & $<10$ & $<10$ \\
\hline
\end{tabular}

$\mathrm{M}_{1}$, milkshake formulated without the addition of whey; $\mathrm{M}_{2}$, milkshake containing $36 \%$ milk and 24\% whey; $\mathrm{M}_{3}$, milkshak econtaining 24\% milk and 36\% whey; MPN, most probable number; CFU, colony-forming units. Source: Authors (2020).

Chocolate milkshakes with chia contained $1.10 \times 10^{3} \mathrm{MPN} / \mathrm{g}$ total coliforms. The presence of coliforms is likely associated with the use of dairy ingredients. Lactic acid 
bacteria are commonly found in dairy products and can multiply in a similar manner to that of coliform bacteria. The concentrations of thermotolerant coliforms $(<3 \mathrm{MPN} / \mathrm{g})$ and yeasts and filamentous fungi $(<10 \mathrm{CFU} / \mathrm{g})$ were low, indicating that raw materials were of good quality and that processing methods were adequate. Partial replacement of milk by whey did not influence the microbiological quality of milkshakes. This result shows that the heat treatment applied to whey was effective in eliminating pathogenic and spoilage microorganisms.

In Brazil, microbiological standards for foods are described in Normative Instruction No. 60/2019. However, the legislation does not determine limits for total and thermotolerant coliforms or yeasts and filamentous fungi in milkshakes (categorized as iced-cold foods) (BRAZIL, 2019). Teixeira et al. (2019) assessed the microbiological properties of three biofortified functional ice cream formulations and found that food items were microbiologically safe for consumption. The concentration of thermotolerant coliforms $(<3$ $\mathrm{MPN} / \mathrm{g}$ ) was similar to that observed in chocolate chia milkshakes.

The proximate composition and energy value of chocolate chia milkshakes are described in Table 3.

Table 3 - Proximate composition and energy value of chocolate chia milkshakes formulated with different concentrations of whey

\begin{tabular}{cccccc}
\hline \multirow{2}{*}{ Parameter } & \multicolumn{3}{c}{ Formulation } & Mean & LSD \\
\cline { 2 - 5 } & $\mathrm{M}_{1}$ & $\mathrm{M}_{2}$ & $\mathrm{M}_{3}$ & & \\
\hline Water (\%) & $76.27^{\mathrm{a}} \pm 0.58$ & $77.11^{\mathrm{a}} \pm 0.89$ & $76.84^{\mathrm{a}} \pm 0.75$ & 76.74 & 2.82 \\
Ash (\%) & $1.92^{\mathrm{a}} \pm 0.09$ & $1.52^{\mathrm{b}} \pm 0.10$ & $1.38^{\mathrm{b}} \pm 0.03$ & 1.61 & 0.21 \\
Protein (\%) & $8.28^{\mathrm{a}} \pm 0.35$ & $8.44^{\mathrm{a}} \pm 0.12$ & $8.83^{\mathrm{a}} \pm 0.30$ & 8.52 & 1.35 \\
Lipid (\%) & $10.72^{\mathrm{a}} \pm 0.41$ & $8.53^{\mathrm{b}} \pm 0.28$ & $6.61^{\mathrm{c}} \pm 0.33$ & 8.62 & 0.68 \\
Carbohydrate (\%) & $2.81^{\mathrm{b}} \pm 0.88$ & $4.39^{\mathrm{ab}} \pm 0.91$ & $6.34^{\mathrm{a}} \pm 0.89$ & 4.51 & 3.05 \\
Energy value (Kcal/100 g) & $140.87^{\mathrm{a}} \pm 0.90$ & $128.12^{\mathrm{b}} \pm 0.96$ & $120.20^{\mathrm{b}} \pm 0.93$ & 129.73 & 10.53 \\
\hline $\mathrm{M}_{1}$, milkshake formulated without the addition of whey; $\mathrm{M}_{2}$, milkshake containing 36\% milk and 24\% whey; \\
$\mathrm{M}_{3}$, milkshake containing 24\% milk and 36\% whey; LSD, least significant difference. Means followed by the \\
same letter do not differ at $p<0.05$ by Tukey's test \\
Source: Authors (2020).
\end{tabular}

Partial substitution of milk by whey did not influence water content ( $p>0.05)$, but $\mathrm{M}_{1}$ contained higher levels $(76.27 \%)$ than $\mathrm{M}_{2}$ (77.11\%), resulting from differences in composition. The water content of chocolate ice cream with orange peel fiber (63-70\%) (BOFF et al., 2013) was lower than that of chocolate milkshakes with chia prepared in this study.

Ash content was highest $(p<0.05)$ in $\mathrm{M}_{1}(1.92 \%)$, differing from that in $\mathrm{M}_{2}$ and $\mathrm{M}_{3}$, which were prepared by partial substitution of milk by whey. This finding indicates that milk has a higher ash content than whey. The use of chia flour probably increased the content of 
minerals, vitamins, and natural antioxidants such as tocopherols and polyphenols, compounds that are commonly found in chia seeds (IXTAINA et al., 2011).

The protein content of milkshakes ranged from $8.28 \%$ in $\mathrm{M}_{1}$ to $8.83 \%$ in $\mathrm{M}_{3}$. It is likely that chia flour contributed to the high protein content of milkshakes. According to Olivos-Lugo, Valdivia-López e Tecante (2010), chia seeds are an important source of protein, with protein contents ranging from 19 to $23 \%$. Rodrigues et al. (2018) reported that the protein content of acai pulp and whey protein ice cream ranged from 3.99 to $10.25 \%$ according to the content of whey; the higher the whey concentration, the higher the protein content. In a study by Barcelos et al. (2019), chocolate ice cream was found to have a protein content of $1.70-3.69 \%$, lower than that of chocolate chia milkshake.

Lipid content was highest $(p<0.05)$ in $\mathrm{M}_{1}(10.72 \%)$. The higher the substitution of milk by whey, the lower the lipid content. According to Santos et al. (2013) and Punia and Dhull (2019), healthy foods have high nutritional quality and low fat contents, contributing to body weight control, reduced energy intake, and decreased risk of cardiovascular diseases.

No differences ( $p>0.05$ ) in carbohydrate content were observed between $\mathrm{M}_{2}$ and the other formulations, although $\mathrm{M}_{1}$ and $\mathrm{M}_{3}$ differed from each other. The parameter was highest in $\mathrm{M}_{3}(6.34 \%)$, which had the highest whey concentration (24\% milk and $36 \%$ whey). Whey is composed of about 5\% lactose, its second major component (PESCUMA et al., 2010; BARUKČIĆ et al., 2015). Risner et al. (2019) stated that lactose is the main carbohydrate in milk and is present at high concentrations in whey. Vettorello et al. (2017) prepared ice cream using whey powder and found the food to contain $15.38-16.93 \%$ carbohydrates.

$\mathrm{M}_{2}$ and $\mathrm{M}_{3}$ had a lower $(p<0.05)$ energy value than $\mathrm{M}_{1}$. The reduction in energy value with the addition of whey was probably associated with the concomitant reduction in lipid content. Although RDC No. 359/2003 (BRAZIL, 2003) does not determine a serving size for milkshake, it can be considered as $60 \mathrm{~g}$, the same serving size of ice cream, which is the food item that most resembles milkshake. On the basis of this value, it was estimated that one portion of chocolate milkshake with chia provides $72.12\left(\mathrm{M}_{3}\right)$ to $84.52 \mathrm{Kcal}\left(\mathrm{M}_{1}\right)$, corresponding to 3.61 and $7.04 \%$ of the total energy value of a $2000 \mathrm{Kcal} /$ day diet.

The physicochemical properties of chocolate milkshakes with chia are presented in Table 4. 
Table 4 - Physico chemical parameters of chocolate chia milkshakes formulated with different concentrations of whey

\begin{tabular}{cccccc}
\hline \multirow{2}{*}{ Parameter } & \multicolumn{3}{c}{ Formulation } & \multirow{2}{*}{ Mean } & \multirow{2}{*}{ LSD } \\
\cline { 2 - 4 } & $\mathrm{M}_{1}$ & $\mathrm{M}_{2}$ & $\mathrm{M}_{3}$ & & \\
\hline Total solids (\%) & $23.73^{\mathrm{a}} \pm 0.58$ & $22.89^{\mathrm{a}} \pm 0.89$ & $23.16^{\mathrm{a}} \pm 0.75$ & 23.26 & 2.82 \\
Titratable acidity (\%) & $0.44^{\mathrm{a}} \pm 0.03$ & $0.44^{\mathrm{a}} \pm 0.01$ & $0.44^{\mathrm{a}} \pm 0.01$ & 0.44 & 0.05 \\
pH & $6.74^{\mathrm{a}} \pm 0.03$ & $6.69^{\mathrm{a}} \pm 0.02$ & $6.65^{\mathrm{b}} \pm 0.02$ & 0.88 & 0.03 \\
Water activity & $0.88^{\mathrm{a}} \pm 0.01$ & $0.88^{\mathrm{a}} \pm 0.01$ & $0.87^{\mathrm{a}} \pm 0.01$ & 6.69 & 0.06 \\
\hline
\end{tabular}

$\mathrm{M}_{1}$, milkshake formulated without the addition of whey; $\mathrm{M}_{2}$, milkshake containing $36 \%$ milk and $24 \%$ whey; $\mathrm{M}_{3}$, milkshake containing 24\% milk and 36\% whey; LSD, least significant difference. Means followed by the same letter do not differ at $p<0.05$ by Tukey's test.

Source: Authors (2020).

Total solids ranged from $22.89 \%$ in $\mathrm{M}_{2}$ to $23.73 \%$ in $\mathrm{M}_{1}$. According to Kozlowicz et al. (2019), low concentrations of total solids may negatively impact the formation of ice crystals, decreasing product quality. Vettorello et al. (2017), in assessing the properties of ice cream composed of whey powder, found that total solids varied from 21.14 to $25.85 \%$, similar to the range observed in the present study.

All milkshakes had a titratable acidity of $0.44 \%$. The $\mathrm{pH}$ was close to neutrality, ranging from 6.65 in $\mathrm{M}_{3}$ to 6.74 in $\mathrm{M}_{1}$; the $\mathrm{pH}$ of $\mathrm{M}_{3}$ was significantly lower $(p<0.05)$ than that of the other formulations. Campidelli et al. (2015) reported blueberry chia ice cream to have a $\mathrm{pH}$ of 5.55 , lower than that of chocolate chia milkshakes.

Water activity also did not differ between milkshakes ( $p>0.05)$. Values ranged from $0.87\left(\mathrm{M}_{3}\right)$ to $0.88\left(\mathrm{M}_{1}\right.$ and $\left.\mathrm{M}_{2}\right)$. Water activity values were high, which, according to Sandulachi (2012), increases susceptibility to microbial growth and biochemical reactions responsible for spoilage.

\section{CONCLUSIONS}

Chocolate milkshakes with chia had good microbiological quality. Partial replacement of milk by whey exerted significant effects on ash, lipid, and carbohydrate contents as well as energy value and $\mathrm{pH}$. Milkshake containing $24 \%$ milk and $36 \%$ whey had the lowest lipid content and energy value and the highest carbohydrate content. The use of whey as a partial substitute for milk is a feasible and innovative strategy to minimize environmental impacts. Further studies should investigate the storage stability and sensory quality of chocolate chia milkshakes. 


\section{REFERENCES}

ALI. ADOLFO LUTZ INSTITUTE. Physico-chemical methods for food analysis. Digital, São Paulo, 2008. 102p. Available in:

https://wp.ufpel.edu.br/nutricaobromatologia/files/2013/07/NormasADOLFOLUTZ.pdf.

Accessed on: May 13, 2020.

ALVES, M. P. et al. Whey: technologies for coproducts production. Journal of Candido

Tostes Dairy Institute, Juiz de Fora, v. 69, n. 3, p. 212-226, 2014. Available in:

https://doi.org/10.14295/2238-6416.v69i3.341. Accessed on: May 13, 2020.

AOAC. ASSOCIATION OF OFFICIAL ANALYTICAL CHEMISTS: Official methods of analysis. 20. ed., Washington, 2016.

BARCELOS, S. C. et al. Microbiological and physico-chemical quality of chocolate flavored ice cream commercialized in the city of Limoeiro do Norte, Ceará, Brazil. Segurança Alimentar e Nutricional, Campinas, v. 26, p. 1-4, e019024, 2019. Available in: http://dx.doi.org/10.20396/san.v26i0.8654452. Accessed on: May 13, 2020.

BARUKČIĆ, I. et al. Influence of high intensity ultrasound on microbial reduction, physicochemical characteristics and fermentation of sweet whey. Innovative Food Science \& Emerging Technologies, v. 27, p. 94-101, 2015. Available in: https://doi.org/10.1016/j.ifset.2014.10.013. Accessed on: May 13, 2020.

BOFF, C. C. et al. Development of chocolate ice cream using orange peel fiber as fat replacer. Ciência Rural, Santa Maria, v. 43, n. 10, p. 1892-1897, 2013. Available in: https://doi.org/10.1590/S0103-84782013001000026. Accessed on: May 13, 2020.

BRAZIL. Ministry of health. RDC Resolution No. 359, of december 23, 2003. Technical regulationofportions of packaged foods for nutrition labeling purposes. Official Journal of the Federal Government of Brazil, Brasília, 2003.

BRAZIL. Ministry of health. RDC Resolution No. 266, of september 22, 2005. Technical regulations for edible ice cream and preparations for edible ice cream. Official Journal of the Federal Government of Brazil, Brasília, 2005a.

BRAZIL. Ministry of health. National health surveillance agency. Mandatory nutrition labeling: food industry guidance manual. 2. version. University of Brasilia, Brasília, 2005b.

BRAZIL. Ministry of health. RDC Resolution No. 60, of december 23, 2019. Establishes lists of microbiological standards for food. Official Journal of the Federal Government of Brazil, Brasília, 2019.

CAPITANNI, M. I. et al. Physicochemical and functional characterization of by-products from chia (Salvia hispanica L.) seeds of Argentina. LWT - Food Science and Technology, v. 45, p. 94-102, 2012. Available in: https://doi.org/10.1016/j.1wt.2011.07.012. Accessed on: May 13, 2020.

CAMPIDELLI, M. L. L. et al. Development of blueberry ice cream (Vaccinium myrtillus) enriched with chia seed (Salvia hispanica). Revista Brasileira de Tecnologia 
Agroindustrial, Ponta Grossa, v. 9, n. 2, p. 1962-1974, 2015. Available in: http://dx.doi.org/10.3895/rbta.v9n2.1820. Accessed on: May 13, 2020.

COELHO, M. S.; SALAS-MELLADO, M. L. M. Review: chemical composition, functional properties and technological applications of chia (Salvia hispanica L.) seeds in foods.

Brazilian Journal of Food Technology, Campinas, v. 17, n. 4, p. 259-268, 2014. Available in: http://dx.doi.org/10.1590/1981-6723.1814. Accessed on: May 13, 2020.

FOLCH, J.; LESS, M.; STANLEY, S. A simple for the isolation and purification of total lipids from animal tissues. Journal Biological Chemistry, v. 226, n. 1, p. 497-509, 1957. Available in:

https://pdfs.semanticscholar.org/f030/d83780d99235c565a9363ff1b3893b542aa5.pdf? ga=2. 146106743.234673531.1590604800-507520272.1584824373. Accessed on: May 13, 2020.

HOLANDA, N. S. O. et al. Effects of differents weeteners in the preparation of drinks composed of cashew (Anarcadium occidentale) and whey. Research, Society and Development, Vargem Grande Paulista, v. 9, n. 5, e88953121, 2020. Available in: http://dx.doi.org/10.33448/rsd-v9i5.3121. Accessed on: May 13, 2020.

IXTAINA, V. Y. et al. Characterization of chia seed oils obtained by pressing and solvent extraction. Journal of Food Composition Analysis, v. 24, n. 2, p. 166-174, 2011. Available in: http://dx.doi.org/10.1016/j.jfca.2010.08.006. Accessed on: May 13, 2020.

KOZLOWICZ, K. et al. U. Effect of ice cream storage on the physicochemical properties and survival of probiotic bacteria supplemented with zinc ions. LWT- Food Science and Technology, v. 16, p. 1-8, 2019. Available in: https://doi.org/10.1016/j.lwt.2019.108562. Accessed on: May 13, 2020.

LIMA, F. R.; ROCHA, L. O. F. Usage of the milk whey originated from serro cheese to manufacture dulce de leche: economic viability. Journal of Candido Tostes Dairy Institute, Juiz de Fora, v. 71, n. 2, p. 83-93, 2016. Available in: https://doi.org/10.14295/22386416.v71i2.526. Accessed on: May 13, 2020.

MADRUGA, K.; ROCHA, M.; FERNANDES, S. S. Properties of wheat and rice breads added with chia (Salvia hispanica L.) protein hydrolyzate. Food Science and Technology, Campinas, v. 40, n. 3, 2020. Available in: https://doi.org/10.1590/fst.12119. Accessed on: May 13, 2020.

MENESES, V. P. et al. Parameters of the physical-chemical, microbiological and sensory quality of sweet pastoso fresh milk serum and milk powder. Global Science and

Technology, Rio Verde, v. 12, n. 2, p. 170-183, 2019. Available in:

https://rv.ifgoiano.edu.br/periodicos/index.php/gst/article/view/1123. Accessed on: May 13, 2020.

OLIVEIRA, N. M. A. L. et al. Physical chemical and sensory characteristics of sandwich loaf enriched with whey protein concentrate and calcium carbonate. Adolfo Lutz Institute Journal, São Paulo, v. 70, n. 1, p. 16-22, 2011. Available in:

http://periodicos.ses.sp.bvs.br/pdf/rial/v70n1/v70n1a03.pdf. Accessed on: May 13, 2020.

OLIVOS-LUGO, B. L.; VALDIVIA-LÓPEZ, M. Á.; TECANTE, A. Thermal and physico chemical properties and nutritional value of the protein fraction of mexican chia seed (Salvia 
hispânica L.). Food Science and Technology International, v. 16, n. 1, p. 89-96, 2010. Available in: https://doi.org/10.1177/1082013209353087. Accessed on: May 13, 2020.

PERRONE, I, T. et al. Processing and physico-chemical characterization of whole whey powder. Journal of Candido Tostes Dairy Institute, Juiz de Fora, v. 69, n. 5, p. 323-333, 2014. Available in: https://doi.org/10.14295/2238-6416.v69i5. Accessed on: May 13, 2020.

PESCUMA, M. et al. Functional fermented whey-based beverage using lactic acid bacteria. International Journal of Food Microbiology, v. 141, n. 1-2, p. 73-81, 2010. Available in: https://doi.org/10.1016/j.ijfoodmicro.2010.04.011. Accessed on: May 13, 2020.

PUNIA, S.; DHULL, S. B. Chia seed (Salvia hispanica L.) mucilage (a heteropoly saccharide): thermal, pasting, rheological behaviour and its utilization. International Journal of Biological Macromolecules, v. 149, p.1-7, 2019. Available in:

https://doi.org/10.1016/j.ijbiomac.2019.08.205. Accessed on: May 13, 2020.

RISNER, D. et al. Volatile aroma composition of distillates produced from fermented sweet and acid whey. Journal of Dairy Science, v. 102, n. 1, p. 202-210, 2019. Available in: https://doi.org/10.3168/jds.2018-14737. Accessed on: May 13, 2020.

RODRIGUES, J. et al. Ice cream sensorial and physical chemistry evaluation with acai pulp and protein milk serum. Ambiência, Guarapuava, v. 14, n. 2, p. 225-236, 2018. Available in: https://revistas.unicentro.br/index.php/ambiencia/article/view/4249/pdf. Accessed on: May $13,2020$.

SANDULACHI, E. Water activity concept and its role in food preservation. Meridian Engineering, v. 4, p. 40-48, 2012. Available in: https://pdfs.semanticscholar.org/d967/adfc525f16a4317f44df48daac42b64b947f.pdf?_ga=2.1 38234611.234673531.1590604800-507520272.1584824373. Accessed on: May 13, 2020.

SANTOS, R. D. et al. Brazilian society of cardiology. I Guideline on fat consumption and cardiovascular health. Brazilian Archives of Cardiology, v. 100, n. 1, p. 1-40, 2013. Available in: http://publicacoes.cardiol.br/consenso/2013/Diretriz_Gorduras.pdf. Accessed on: May 13, 2020.

SILVA, A. M. T. et al. Elaboration of yogurt with functional properties using Bifidobacterium lactis and soluble fiber. Revista Brasileira de Produtos Agroindustriais, Campina Grande, v. 16, n. 3, p. 291-298, 2014. Available in: http://www.deag.ufcg.edu.br/rbpa/rev163/Art1638.pdf. Accessed on: May 13, 2020.

SILVA, F. A. Z.; AZEVEDO, C. A. V. The assistat software version 7.7 and its use in the analysis of experimental data. African Journal of Agricultural Research, v. 11, n. 3, p. 3733-3740, 2016. Available in: https://doi.org/10.5897/AJAR2016.11522. Accessed on: May 13, 2020.

SILVA, N. et al. Manual of methods for microbiological analysis of food and water. 5. ed. São Paulo: Blucher, 2017. Available in:

https://books.google.com.br/books?id=ki9dDwAAQBAJ\&printsec=frontcover\&hl=pt-

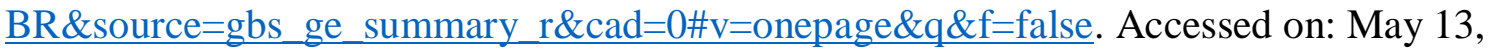
2020. 
SOUZA, R. C. P. et al. Bioprocess technology for production of functional foods. Journal

Agro@mbiente On-line, Roraima, v. 7, n. 3, p. 366-372, 2013. Available in:

http://dx.doi.org/10.18227/1982-8470ragro.v7i3.1240. Accessed on: May 13, 2020.

TEIXEIRA, F. R. et al. Development of biofortified ice cream with functional characteristics.

FAG Journal of Health, v. 1, n. 2, p. 97-107, 2019. Available in:

http://dx.doi.org/10.35984/fjh.v1i2.83. Accessed on: May 13, 2020.

TESSER, I. C. et al. Preparation of cheese bread added with whey powder. Journal of

Candido Tostes Dairy Institute, Juiz de Fora, v. 65, n. 372, p. 3-8, 2010. Available in: https://www.revistadoilct.com.br/rilct/article/view/109. Accessed on: May 13, 2020.

VETTORELLO, G. et al. Preparation of ice cream with the addition of powdered cheese whey. Academic Highlights Journal, Lajeado, v. 9, n. 4, 2017. Available in:

http://dx.doi.org/10.22410/issn.2176-3070.v9i4a2017.1662. Accessed on: May 13, 2020.

VILELA, M. E. et al. Sensory and physico chemicale valuation of pasty dulce deleche containing different concentrations of whey. Journal of Candido Tostes Dairy Institute, Juiz de Fora, v. 75, n. 1, p. 22-33, 2020. Available in: http://dx.doi.org/10.14295/22386416.v75i1.767. Accessed on: May 13, 2020.

\section{AUTHOR INFORMATION}

\section{Julimeri Câmara Costa}

E-mail: july_camara99@hotmail.com

Curriculum Lattes: http://lattes.cnpq.br/1031037864589102

Food Technician by the Federal Institute of Education, Science and Technology of Rio Grande do Norte, Pau dos Ferros-RN campus.

\section{Emanuel Neto Alves de Oliveira}

E-mail: emanuel.oliveira16@gmail.com

Curriculum Lattes: http://lattes.cnpq.br/8785951951414869

Graduated in Food Technology from the Faculty of Technology CENTEC - Cariri (2009). Specialist in Chemistry Teaching by the Regional University of Cariri (2009), in Food Science by the Federal University of Pelotas (2012) and in Public Management by the IFRN (2020). Master (2012) and Doctor (2016) in Agricultural Engineering in the Area of Concentration in Processing and Storage of Agricultural Products by the Federal University of Campina Grande. He has a Post-Doctorate in Chemical Engineering from the University of Coimbra, Portugal (2018) in the area of Technology and Quality Control of Wines. He is a Professor at the Federal Institute of Education, Science and Technology of Rio Grande do Norte (IFRN), based on the Pau dos Ferros/RN campus where he currently holds the position of General Director of the campus. He has experience in the field of Agricultural Engineering and Food Science and Technology, working mainly on the following topics: Drying and Storage of Agricultural Products, Food Processing of Vegetable and Animal Origin, Physical and Chemical Analysis of Food and Quality Control. He is a permanent professor of the Academic Master's Course in Teaching of the Graduate Program in Teaching (PPGE) of the Advanced Campus of Pau dos Ferros (CAPF), of the State University of Rio Grande do Norte (UERN) in the line of research of Teaching Exact and Natural Sciences. Currently, he also 
works at the National Institute of Educational Studies and Research Anísio Teixeira (INEP) as an institutional appraiser of higher education institutions.

\section{Kaísa Mikelly Pereira Oliveira}

E-mail: kaisa mikelly@ hotmail.com

Curriculum Lattes: http://lattes.cnpq.br/4031803729316210

Food Technician by the Federal Institute of Education, Science and Technology of Rio Grande do Norte, Pau dos Ferros-RN campus.

\section{Rerisson do Nascimento Alves}

E-mail: rerisson-alves@hotmail.com

Curriculum Lattes: http://lattes.cnpq.br/3427416952900222

Food Engineer from the Federal University of Campina Grande (2017). He is currently studying for a Master's Degree in Agri-Food Technology at the Federal University of Paraíba (UFPB). He was a fellowship monitor in the Cytology and Histology discipline for 6 consecutive periods (2013.1 to 2015.2). He participated in scientific initiation projects in the manufacture of rennet-type goat's milk cheeses and the development of quality indicator packaging for food. He gave a lecture to slaughterhouse owners in the municipality of Pombal-PB with the theme "Good Handling Practices for Refrigerators". He worked as a collaborator in the Project for the Development of Goat Breeding in the Semi-Arid Region of Paraíba. He has experience in the area of Food Science and Technology, with an emphasis on cytology and histology, quality control, technology of animal products and food packaging technology.

\section{Bruno Fonsêca Feitosa}

E-mail: brunofonsecafeitosa@live.com

Curriculum Lattes: http://lattes.cnpq.br/6593307184392271

Food Technician (IFRN, 2016). Academic in Food Engineering (UATA/CCTA/UFCG, 2017.1). He received a scholarship from the Foundation Paraíba Technological Park (PaqTcPB) and the National Council for Scientific and Technological Development (CNPq). Research in the area of Food Science and Technology, with experience in analysis and quality control of food, technology and processing of fruit and milk, development of new products and use of agro-industrial residues.

\section{Rosane Liege Alves de Souza}

E-mail: rosaneliege@yahoo.com.br

Curriculum Lattes: http://lattes.cnpq.br/2994260248217828

Graduated in Chemical Engineering from the Federal University of Campina Grande (2006) and Master in Chemical Engineering from the Federal University of Campina Grande (2008). $\mathrm{PhD}$ in Chemical Engineering (2014) with expertise in Science and Technology of plant and animal foods, quality control and product storage, bioactive compounds of fruits and sensory analysis. 